Old Dominion University ODU Digital Commons

2015

\title{
Intertemporal Elasticity of Substitution and Risk Aversion: Are They Related Empirically?
}

Takeshi Yagihashi

Old Dominion University

Juan $\mathrm{Du}$

Old Dominion University

Follow this and additional works at: https://digitalcommons.odu.edu/economics_facpubs

Part of the Economics Commons

\section{Repository Citation}

Yagihashi, Takeshi and Du, Juan, "Intertemporal Elasticity of Substitution and Risk Aversion: Are They Related Empirically?" (2015). Economics Faculty Publications. 24.

https://digitalcommons.odu.edu/economics_facpubs/24

\section{Original Publication Citation}

Yagihashi, T., \& Du, J. (2015). Intertemporal elasticity of substitution and risk aversion: are they related empirically? Applied Economics, 47(15), 1588-1605. doi: 10.1080/00036846.2014.1000530 


\title{
Intertemporal Elasticity of Substitution and Risk Aversion: Are They Related Empirically?
}

\author{
Takeshi Yagihashi and Juan Du \\ Nov. 2014 \\ Department of Economics, Old Dominion University, Norfolk, VA
}

\begin{abstract}
This paper examines the relationship between two types of preference: preference of intertemporal choices and preference towards risk. In the simplest form of the constant relative risk aversion utility function, the intertemporal elasticity of substitution (IES) and risk aversion has an inverse relationship. However, there is no empirical evidence that suggests this inverse relationship holds. We examine the relationship between risk aversion and IES using household consumption data from the Consumer Expenditure Survey during 1996 -2010. Multiple risk domains are selected to represent risk preference; for each domain we consider some households to be more risk averse than others. We separately estimate IES for the more risk averse households and the less risk averse households. We find that the IES estimates are generally smaller for the more risk averse households than for the less risk averse households and the difference is statistically significant in majority of the financial domains. This finding supports the inverse relationship between the two parameters, though considerable heterogeneity is found across domains.
\end{abstract}

Abstract Word Count: 166

Key words: intertemporal elasticity of substitution, risk aversion, health behavior, financial market participation, preference heterogeneity

JEL classification: D91, D81, E20, I10 


\section{Introduction}

Intertemporal elasticity of substitution (IES) shows how strongly households substitute their current consumption against future consumption in response to a change in the economywide real interest rate. The degree of substitution affects how households accumulate their wealth over the life cycle through saving at a given point in time. Since Hall (1978), the Euler equation approach, i.e., the first order condition derived from an intertemporal optimization problem, is often used to estimate IES. In modern macroeconomics, IES plays a central role in fitting the standard business cycle model to data (Jones et al., 2000). In addition, the effect of government policies on the overall economy also depends on the size of IES (King and Rebelo, 1990).

In a typical macro model, a representative household's utility function is modeled using a power function that exhibits constant relative risk aversion (CRRA). In the simplest form of the CRRA utility function, IES can be analytically derived as the inverse of risk aversion. This would make sense if we consider the fluctuation in the marginal utility of consumption over time as a form of risk and a risk-averse individual would actively participate in the financial market to smooth their consumption path to avoid such a risk. Although the CRRA utility function is sometimes considered too restrictive in explaining the behavior of aggregate variables such as equity premium, it has been used widely in economic models to this day, mainly because of its simplicity and tractability.

Despite the importance of the CRRA utility and IES in macroeconomic models, little do we know whether intertemporal choices are related to risk preference at the micro level. In this paper, we investigate this point further by using household consumption data from the Consumer 
Expenditure Survey (CE). Since it is difficult to estimate IES and risk aversion simultaneously using the Euler equation approach, we first define subsamples of households based on their risk preference and then estimate IES for the subsamples separately. We do not attempt to verify the exact inverse relationship between the two parameters, ${ }^{1}$ instead we examine whether IES and risk aversion is negatively associated with each other as implied in the CRRA utility. We test this hypothesis by comparing the size of the IES estimates between the subsamples of households with different risk preferences. If the IES turns out to be larger for the more risk averse group, it suggests that the inverse relationship between IES and risk aversion does not hold empirically and the CRRA utility function may be too restrictive in its preference specification.

The challenge of this approach lies in how to define risk preference. Previous studies in the risk literature suggest that many risk behaviors reflect the underlying preference of the individual (Barsky et al., 1997; Dohmen et al., 2011). Our approach does not rely on a single risk preference measure based on hypothetical questions; instead we define seven risk domains that are constructed based on households' actual behavioral and financial choices. This multidomain approach allows for heterogeneity of risk preference, e.g. one household can be risk averse in one domain but risk loving in another domain.

There are two main findings. First, consistent with the construct of the CRRA utility, in five of the seven risk domains the estimate of IES is smaller for the more risk averse group than for the less risk averse group. The two exceptions are in domains of health insurance and heavy alcohol drinking, which we find reasonable given the nature of these risk measures. Second, although the IES estimates differ across domains, majority of the estimates fall within the unit

\footnotetext{
${ }^{1}$ The exact inverse relationship will not hold if further structures are introduced in the model. For example, Swanson (2012) shows that if households are allowed to adjust their hours worked, then the exact inverse relationship would not hold.
} 
interval. This suggests that allowing for preference heterogeneity helps in overcoming aggregation bias. Our results remain fairly robust to alternative specifications, such as excluding households with liquidity constraint or excluding the period of the Great Recession, among others.

This paper contributes to the literature in several ways. First, to our knowledge this is the first study that examines the empirical relationship between intertemporal choices and risk preference using household-level consumption data. This relationship is important given the trend for using more complicated utility function such as the Epstein and Zin specification in the literature. Second, we provide further evidence on the heterogeneity of intertemporal choices. Earlier studies estimated IES for different demographic groups such as age, marital status, and gender (Attanasio and Weber, 1989, 1993, 1995). While this approach does help in explaining some variations in the existing IES estimates, our approach based on risk preference provides a more straightforward reasoning as well as a method for direct comparison of IES estimates from subsamples. Lastly, we use a nationally representative data, the Consumer Expenditure Survey (CE), to construct our risk measures. The dataset has been collected on a regular basis since 1980 and the broad coverage of household consumption categories suits our purpose in this paper. While the CE has been widely used in estimating IES, it has been largely ignored in the risk literature.

Our paper fits in the broad literature of heterogeneous households. A review paper, Heathcote et al. (2008), explain the source of individual risk and heterogeneity in terms of family background, initial endowment, educational choices, labor supply, occupation choices, and health and family shocks. Recent studies have emphasized the role of household heterogeneity. For example, Schulhofer-Whol (2008) documents that less risk-averse individuals have a larger 
earning fluctuation during their lifetime and further examines the role of heterogeneous risk preferences in the context of business cycle. Krusell and Smith (1998) use random discount factors to explore the heterogeneity of income and wealth distribution in the macro-economy.

This paper is organized as follows. The next section explains theory and model. The third section explains the estimation method. The fourth section provides details on the CE sample. The fifth section discusses the results. The last section concludes.

\section{Theoretical Framework}

Our theoretical framework is based on the utility specification that is widely used in structural macroeconomic models or life-cycle models. A representative household maximizes its lifetime utility that consists of expected future streams of goods consumption $C$. The utility maximization process can be written as

$$
\max E_{t} \sum_{i=0}^{\infty} \beta^{i} u\left(C_{t+i}\right)
$$

where $u\left(C_{t}\right) \equiv C_{t}^{1-\gamma} /(1-\gamma)$ and the preference parameter $\beta$ is the subjective discount factor. $\gamma$ is the Arrow-Pratt measure of relative risk aversion for the period utility function $u\left(C_{t}\right)$, which can be obtained as $\gamma=\frac{-C u^{\prime \prime}(C)}{u^{\prime}(C)}$. Because $\gamma$ is constant, this type of utility function is referred to as the constant relative risk aversion (CRRA) utility function.

Households maximize utility based on the following budget constraint 


$$
C_{t}+\frac{D_{t+1}}{P_{t}}=\frac{W_{t}}{P_{t}}+\frac{R_{t}^{n}}{P_{t}} D_{t}+\text { profit }_{t}
$$

where $D_{t}$ is a one-period nominal coupon bond maturing at time $t$ and paying a gross nominal interest rate $R_{t}^{n}$. $W_{\mathrm{t}}$ is the nominal wage, which is determined in a competitive factor market and $P$ is the economy-wide aggregate price index. For simplification, we normalize labor supply to be unity. profit is the sum of real profits collected as a lump-sum from various types of firms.

The first order necessary condition leads to the following intertemporal efficiency condition known as the Euler equation:

$$
C_{t}^{-\gamma}=\beta R_{t+1}^{n} E_{t}\left[\frac{C_{t+1}^{-\gamma}}{\Pi_{t+1}}\right]
$$

where $\Pi_{t+1} \equiv P_{t+1} / P_{t}$ is the aggregate gross inflation. This condition says that the marginal cost of foregoing one unit of goods today is equal to the marginal benefit of consuming the same goods in the next period.

Based on our model setting, it is straightforward to show that the inverse of the risk aversion coefficient $(1 / \gamma)$ represents IES, i.e. how strongly households substitute between their current consumption and future consumption in response to the real interest rate. If the utility function is concave $(\gamma>0)$, agents prefer a smooth path of consumption to a variable one. In other words, consumers act to keep the marginal utility of consumption constant over time. A large and positive value of $\gamma$ or a small IES indicates strong preference to avoid fluctuations in consumption.

There have been many attempts in the literature to estimate IES under the CRRA utility framework. Earlier estimates using aggregate data tend to vary widely depending on the sample 
and method used (Hansen and Singleton, 1983, 1996) and later studies have tried to reconcile the difference in these estimates (Hall, 1988; Ogaki and Reinhart, 1998). There are several possible explanations for the wide range of empirical estimates (including negative ones). First, it could be because the CRRA utility specification is too restrictive, leading to a rejection of the theoretical model. One alternative approach is to use a more flexible preference specification that does not restrict IES and risk aversion to be inversely related, as proposed by Epstein and Zin (1989). However, with the Epstein and Zin specification, one can no longer apply the usual linearization technique to estimate parameters and it is not possible to identify IES and risk aversion at the same time without imposing further restrictions (Attanasio and Vissing-Jørgensen, 2003).

Second, individual heterogeneity in preference could conflict with the representative household assumption imbedded in the model. ${ }^{2}$ Attanasio and Weber (1993) argue that estimates using aggregate data are considerably lower than those using cohort-level data and that the theoretical model is often rejected with aggregate data. This result is often interpreted as the consequence of combining individuals with different preferences into one group and forcing them to have identical coefficients. Other studies estimate IES using cohort-level micro data and find that the model is not rejected once demographic and leisure activities are taken into account (Attanasio and Weber, 1995; Blundell et al.,1994).

In this paper, we develop the second point further by examining the role of individual heterogeneity using households' risk preference. Specifically, we estimate IES for two types of households that exhibit different risk preferences while assuming the conventional CRRA utility for each. Suppose there are two distinct groups of households indexed as $k=M R A, L R A$, where

\footnotetext{
${ }^{2}$ Alternatively, it could be because of the identification problem associated with the estimation method (Stock and Wright, 2000; Neely et al., 2001; Yogo, 2004).
} 
the letters stand for "more" risk averse (MRA) households and "less" risk averse (LRA) households. According to a specific risk criterion $j$, we assume that $\gamma_{j, M R A}>\gamma_{j, L R A}$ holds. If the CRRA utility is truly structural, we expect that $I E S_{j, M R A}<I E S_{j, L R A}$ for any $j$. If the CRRA utility is mis-specified and risk aversion is not related to IES, then for a given $j$, IES for the MRA and LRA households could take any values and the relative size of the IES is indeterminate.

\section{Estimation Method}

III.A. Pseudo-panel approach

We largely follow Attanasio and Weber (1995) that use a pseudo panel data approach to estimate IES. A pseudo panel is constructed by treating households in the same cohort as one individual who is then followed throughout the entire sample period. Each cohort is determined by the birth year of the reference person in a household. By using the pseudo panel approach, we can capture the cohort fixed effects that arise from each generation's common lifetime experience such as recession, high inflation, or risky asset market crash and avoid attrition bias. The pseudo panel approach has several well-known advantages as detailed in length in Chamberlain (1984) and Hayashi (1987). ${ }^{3}$

The difference between our approach and Attanasio and Weber (1995) is that our samples are separated based on households' risk preference and the IES for the subsamples are estimated jointly in a GMM framework. Identification is through moment conditions formulated using the linearized Euler equation, which is typical in the literature. Cohort-based consumption growth is

\footnotetext{
${ }^{3}$ Some of the benefits include the following. First, averaging over individuals that belong to the same group helps to remove additive idiosyncratic measurement errors. Second, it reduces attrition bias because (unlike individual households) each cohort exists for the entire sample period. Third, it allows households in the same cohort to be correlated ("cohort effect"). Fourth, it averages out expectation errors and makes the estimates more likely to be consistent under given instruments.
} 
obtained by first taking the growth rate of consumption for each household over two consecutive quarters and then taking the average of these growth rates for a given cohort in a given period. By aggregating this way, we reduce the bias caused by serially correlated errors, which often exist in aggregate data. We also ensure that growth rate is constructed using the same household across two periods, thus any change in consumption growth is not caused by changes in sample compositions (e.g. marriage, divorce, and child birth).

\section{III.B. Euler equation}

By construction, we keep households that have data available for at least two consecutive quarters. To avoid outliers within each cell to contaminate our result, we drop households whose quarterly consumption changes by above five folds. ${ }^{4}$ The log-linearized consumption Euler equation can be written as follows,

$$
\begin{gathered}
\frac{1}{H} \sum_{h} \Delta \ln \left(C_{t+1}^{h}\right)=\text { constant }+\frac{1}{\gamma} \ln \left(1+R_{t+1}^{n}\right)+\theta^{\prime} \frac{1}{H} \sum_{h} \Delta \ln \left(z_{t+1}^{h}\right)+\frac{1}{H} \sum_{h} \epsilon_{t+1}^{h} \\
h=1,2 \ldots \mathrm{H}
\end{gathered}
$$

where $\mathrm{H}$ is the number of households satisfying a particular criterion within a given cohort in a given period. $C$ is nondurable consumption and $z$ is the vector of household demographic variables and leisure activities, including family size, single status, number of children, wife fulltime status, wife leisure per week, and seasonal dummies. $\frac{1}{\gamma}$ is the marginal rate of substitution between today and tomorrow's consumption. A decrease in the real interest rate increases the price of future consumption relative to current consumption, inducing more consumption today.

\footnotetext{
${ }^{4}$ Vissing-Jørgensen (2002) and Brav et al. (2002) drop observations based on stricter criterions. In addition to our criterion, they also dropped households whose consumption growth satisfies $\mathrm{C}_{\mathrm{t}} / \mathrm{C}_{\mathrm{t}-1}>2$ and $\mathrm{C}_{\mathrm{t}} / \mathrm{C}_{\mathrm{t}-1}<0.5$. We also conducted analysis using the stricter criterion and results are quite similar.
} 
The error structure in equation (1) is complicated because one household may appear in four consecutive quarters (three growth rates) and there may be artificial heteroskedasticity arising from different cell sizes for different subsamples. We apply a weight matrix allowing for both heteroskedasticity and autocorrelation up to four lags.

We estimate Euler equations for the two subsamples (MRA and LRA) jointly as a system. We prefer joint estimation to separate estimation for two reasons. First, joint estimation allows the errors of the two equations to be correlated, improving efficiency. In addition, it is reasonable to expect that some common macroeconomic shocks affect consumption of every household. Second, joint estimation allows us to conduct statistic analysis to test equality of the IES estimates across subsamples.

III.C. Notes on instruments

The GMM approach relies crucially on the choice of instruments. One problem of working with the subsamples is that the cell size can be small for some of the subsamples, which induces a spurious MA(1) structure in the error term and the first lagged endogenous variables become invalid instruments. To mitigate this problem, we discard the first lag and use further lagged variables as our instruments. ${ }^{5}$ Three seasonal dummies and a constant are also included as instruments. These choices of instruments closely follow the literature. ${ }^{6}$

Another problem associated with the instruments is that the same household may appear for a maximum of four consecutive quarters in the $\mathrm{CE}$. Using information of the same households to construct instruments may lead to inconsistent estimates due to potential

\footnotetext{
${ }^{5}$ In particular, we use the second, third, and fourth lag of consumption growth, nominal interest rate of the 3-month treasury bill, inflation, labor income growth, and the second and third lags of the change in the (log of) family size, average age of the cohort, wives' full-time status, and wives' leisure.

${ }^{6}$ See Attanasio and Weber (1995) among others.
} 
correlation between the instruments and the errors. When constructing instruments, we make sure that past variables from the same households are not used to construct instruments for themselves. For example, for instruments that are lagged for two quarters, only households from the fourth wave of interview are used. This is because households in the fourth interview would no longer appear in future interviews.

\section{The Consumer Expenditure Survey}

The Consumer Expenditure Survey (CE) is a household survey conducted by the Bureau of Labor Statistics (BLS). It records household expenditures on a wide variety of items, along with household demographic information. Each household is interviewed once per quarter for a maximum of five consecutive quarters and four of them are available to the public. ${ }^{7}$ In each quarter, about $20 \%$ of the households are replaced by newly selected households based on sampling criterion of the CE. ${ }^{8}$ The number of households interviewed in each quarter is spread evenly across three months, and approximately 1,500-2,000 households are interviewed per month about their expenditures in the three months prior to the interview month. ${ }^{9}$ Following Attanasio and Weber (1995), we only count consumption in the month immediately before the interview month and discard consumption of the earlier two months. This avoids complicated error structure arising from having monthly spending over different quarters and also reduces potential recall bias that may arise from elapsed time.

\footnotetext{
${ }^{7}$ In the CE, a household is a consumer unit (CU). A CU consists of two cases: (1) two or more people related by marriage, blood, adoption, or other legal arrangement and make joint financial decisions; (2) a person living alone, or sharing a house with others or lodging home. This person must be financially independent. A reference person is identified in each consumer unit as the person who rents or owns the house. The term "household" is used in this paper to mean "consumer unit".

${ }^{8}$ This short panel feature is used to construct variables with consistency, a point we will explain in the next section.

${ }^{9}$ The households interviewed in the same month can be from any of the five waves due to the rotating nature of the CE.
} 
We exclude households whose reference person is older than 64 or younger than 20 years old. By dropping these two groups, we ensure that households within each cohort stay homogenous over time. Studies find that households on the verge of retirement change their spending behaviors (Aguiar and Hurst, 2005). To mitigate measurement errors, we follow Cogley (2002) and others by excluding households that have incomplete income reports and households that have negative entries for food expenditures.

To construct pseudo panel, we set the interval of cohort to five years, which is standard in the literature (Attanasio and Weber, 1995; Fernandez-Villaverde and Krueger, 2007). ${ }^{10}$ Our final data contain six cohorts who are born in 1946 - 1950, $1951-1955,1956-1960,1961-1965$, $1966-1970$, and 1971 - 1975. The age range in our sample is 21-50 in 1996 and 35-64 in 2010.

Our sample length is 60 quarters from 1996Q1 to 2010Q4. Four observations are lost for each cohort because four lags are used to construct instruments. Total observations used in estimation is $336(=6 \times(60-4))$.

IV.A. Consumption and other household variables

Household consumption includes the following nondurable goods and services: food, alcohol beverages, tobacco and smoking, apparel and services, household operation, utility and fuels, gasoline, maintenance and repairs, vehicle-related expenses ${ }^{11}$, public transportation, reading, fees and admissions, maintenance and insurance, baby day care, domestic services, and personal care. Rent, education, and health-related goods and services are not included in our

\footnotetext{
${ }^{10}$ There is a tradeoff. Small intervals yield more homogenous cohorts and considerable variations among cohorts whereas large intervals reduce sampling noises.

${ }^{11}$ Vehicle-related expenses consist of car insurance, rental, leases, licenses, finance charges, and other charges.
} 
definition. Consumption expenditure is converted into real term by deflating it with the price index for nondurable goods obtained from the Bureau of Economic Analysis (BEA).

We take into account demographic information and leisure activities by including family size, marital status, number of children who are less than 18 years old, whether wife works full time, and wife's leisure time per week. We include wives' work status because they are known to affect consumption behavior at the household level. For example, Attanasio and Weber (1993) find that the presence of a working wife increases consumption for young and middle aged cohorts but decreases consumption for older cohorts. Full time is defined as 40 hours of work per week and leisure time is measured as the fraction of non-work hours over total hours available per week (that is, 16 hours/day*7days $=112$ hours).

IV.B. Risk preference measures

While it is common practice in economics to assume one representative underlying risk preference that applies to all contexts (Kimball, 1993), such an assumption is not warranted. Recent studies confirm that certain risk behaviors such as smoking, drinking, purchasing insurance, and occupation choices reflect individuals' underlying risk attitude; but they also point out that individual decisions may be influenced by the context of choice (Anderson and Mellor, 2008; Barsky et al., 1997; Cutler et al., 2008; Dohmen et al., 2011; Einav et al., 2013). For example, Einav et al. (2013) examine employees' health insurance and 401(k) choices and find that only $30 \%$ of times people make consistent choices across all domains. Dohmen et al. (2011) use a large survey and find that risky behaviors across domains (such as, smoking, selfemployment, investment in stocks, active in sports, and traffic offenses) are strongly correlated; but they also point to the value of examining context-specific questions. 
Following the literature, we use multiple domains to define a household's risk preference: (1) health insurance, (2) life insurance, (3) smoking, (4) heavy drinking, (5) employer characteristics, (6) pension plan contribution, and (7) financial market participation. Smoking and heavy drinking are defined using actual expenditure on related items while other risk domains are constructed based on household self-reported status. Domain definitions are shown in Table 1 and explained below.

A household is defined as insured as long as at least one health insurance policy was reported at the time of the interview. In other words, as long as one person in the household is insured, the household is defined as insured. $88 \%$ of the households are insured according to our criterion. ${ }^{12}$ We define life insurance in a similar way as health insurance. Households that reported at least one life insurance policy are regarded as having life insurance, where life insurance is broadly defined as life insurance policy and "other policies that provide benefits in case of death or disability". ${ }^{13} 60 \%$ of the households have at least one life insurance policy in our sample. Households with health insurance (MRA) are considered to be more risk averse than households without health insurance (LRA). Similarly, households with life insurance (MRA) are considered to be more risk averse than households without life insurance (LRA).

We define smokers as those who had positive expenditure on tobacco and smoking supplies in any of the waves they are interviewed. ${ }^{14}$ In our sample, $36 \%$ are considered as smokers. In a similar fashion, we define alcohol drinkers. We use a heavy drinker definition because moderate drinking is not typically perceived as a health risk. We define heavy drinkers

\footnotetext{
${ }^{12}$ The CE reports the total number of policies and the number of persons covered under each policy. We use total number of policies multiplied by the number of persons covered under each policy then divide by family size to obtain average number of policies per person. If this number is 0 or between 0 and 1 , we define the household as uninsured (or under-insured).

${ }_{13}$ This is based on the CE questionnaire.

${ }^{14}$ In an alternative specification, we use a regular smoker definition. If a household has positive expenditures in all interview waves, they are defined as regular smokers. $20 \%$ are regular smokers. The results are very similar when we use the regular smoker definition.
} 
by using household expenditure on alcohol beverages both at home and away from home (e.g. restaurants, bars, or fast food places). Specifically, heavy drinkers are defined as households that spent more than $\$ 100$ on alcohol beverages in all interview waves. In our sample, $14 \%$ is heavy drinkers. Smokers and heavy drinkers are considered to be the LRA group whereas non-smokers and non-heavy-drinkers are considered to be the MRA group.

For job characteristics, we consider government employment status. Most people regard government employment as a relatively stable job that provides good long-term benefits. A household is considered to be more risk averse (MRA) if at least one household member was employed in the federal, state, or local government. $79 \%$ of the households that do not meet this criterion are considered to be less risk averse (LRA), and they consist of private sector employed (60\%), self-employed (12\%), and without jobs (7\%).

We define high pension contributors as households that contributed more than $2 \%$ of their before-tax income in a government/railroad/private pension plan and / or social security in the three months before the interview. Low contributors are defined as households that contributed less than $2 \%$ of their income or did not contribute at all. According to our criterion, $33 \%$ is high pension contributors (MRA), and they are considered to be more risk averse than low contributors (LRA).

The last domain we examine is financial market participation. We use information from the question "what was the estimated value of securities, such as stocks, mutual funds, private bonds, government bonds or Treasury notes owned by you (or any members of your CU) on the last day of (last month)?" This question includes not only risky assets such as stocks and mutual funds and private bonds but also includes relative safe assets that are readily convertible to risky 
assets. $16 \%$ of the households report a positive amount and they are regarded as financial market participants. The CE is known for undercounting stockholders. Vissing-Jørgensen (2002) further added retirement account to their stock variable definition. We do not do so because retirement account is used as a separate risk domain (pension contribution). Financial market participants (LRA) are considered to be less risk averse than non-participants (MRA).

IV.C. Cohort summary statistics

In Table 2, we provide cohort-level summary statistics for the risk variables and household demographic variables. The youngest cohort (born during 1971-1975) has the highest percentage without health insurance (15\% vs $9 \%)$ and life insurance (52\% vs 33\%) compared with the oldest cohort (1946 - 1950). The youngest cohort also has a smaller percent working in the government (77\% vs $82 \%$ non-government), contributing a lower amount to retirement accounts ( $66 \%$ vs $72 \%$ contributing $<2 \%$ income to retirement), and less likely to participate in the financial market (10\% vs $20 \%$ participants). Smokers (35\% of the sample) and heavy drinkers (14\%) are fairly evenly spread across cohorts. The cohorts also differ in demographic characteristics. For example, the cohorts of 1961-1970 (in their 20s and 30s in our sample) tend to have a larger family size and more children. Household income peaks for the 1951- 1960 cohorts who are in their later 30s and 40s. Nondurable consumption has some variations across cohorts as well, with middle-aged cohorts having the highest spending (about $\$ 4,900$ per quarter); and the youngest cohort, the lowest (about $\$ 4,200$ per quarter).

\section{Results}

V.A. Consumption profiles 
Before we discuss the main results, we would like to provide some basic summary statistics on household consumption growth and cohort consumption profiles in different risk domains.

Mean and standard deviations of consumption growth and average cell size for each subsample are shown in Table 1. Average cell size (the last column of Table 1) refers to the number of observations per cohort per quarter. One of the criterions in defining subsamples is to ensure the average cell size of each subsample is large enough $(>50)$ to avoid possible measurement errors. Most of the cell sizes are above 150 with a few exceptions (uninsured and heavy drinkers). We observe that quarterly average consumption growth rates are close to zero or negative, reflecting the slow growth of real income during this period with negative growth during two recessions. The standard deviations of consumption are generally smaller for the MRA group compared with the LRA group except for life insurance and pension contribution.

In Figure 1, we plot life cycle consumption path for each pair of subsamples (e.g. smokers vs non-smokers). ${ }^{15}$ We observe several features from this figure. First, most consumption profiles are hump-shaped reflecting life cycle patterns of consumption. It is important to take into account demographics because family size and work hours are also hump shaped and peak before retirement. Second, in all cases the level of consumption differs between the MRA and LRA group. Consumption for the MRA group is generally higher than the LRA group except for heavy drinking and financial market participation. Third, fluctuation of consumption across cohorts (or consumption smoothness) differs between the MRA and LRA group. Recall that there is a five-year interval between cohorts and our sample covers fifteen years between 1996 and 2010. This means that each cohort has a ten-year overlap with the

\footnotetext{
${ }^{15}$ Each data series is smoothed with the Lowess smoothing to produce the average in a cell.
} 
neighboring cohorts. In the case of health insurance, life insurance, government employment, pension contribution, and financial market participation, the MRA group has a smoother consumption profile than the LRA group. For drinking and smoking, the MRA and LRA group are almost indistinguishable. Some of the gaps between cohorts may reflect generational differences or cohort effects (which we control in our estimation) while others may reflect fluctuation within the same cohort. In sum, Figure 1 shows that households that are less risk averse are more likely to have a volatile consumption profile.

V.B. Correlation among domains

We next examine how individual household's decisions across risk domains are correlated. We use an indicator variable to define each risk domain, with 1 indicating the LRA group (risk takers) and 0 indicating the MRA group (non-risk-takers). Table 3 reports the spearman correlation coefficient for each pair of variables. Among the 21 pairs, 12 pairs have significantly positive correlation coefficient at 5\% level of significance. The correlation coefficients range from 0.04 to 0.27 . Positive correlations are observed mainly among similar categories. For example, without health insurance and without life insurance has the largest correlation of 0.27 ; non-government employment and low pension contribution has a positive correlation of 0.15 . We also find two domains that show some negative correlations with other domains and they are heavy drinkers and financial market participants. Overall, our results are consistent with the literature that finds correlations among similar risk categories are large and positive. For example, Einav et al. (2013) show that correlations among several health insurance choices are high (0.2-0.3) but the correlation between health insurance and $401 \mathrm{~K}$ plans is fairly small $(0.03-0.06)$ 


\section{V.C. IES Estimates}

In this section, we estimate IES for the MRA and LRA group in each risk domain. We then test the null hypothesis $\mathrm{H}_{0}: I E S_{M R A}-I E S_{L R A} \geq 0$. We also report the Hansen's J statistics for each domain. Baseline results are reported in Table 4.

In our baseline specification, we find that for five of the seven risk domains, the MRA group has a lower IES estimate than the LRA group and the difference is statistically significant. The five domains are life insurance, cigarette smoking, government employment, pension contribution, and financial market participation. The remaining two domains that are inconsistent with the inverse relationship are health insurance and heavy drinking.

Second, all estimates for the MRA groups are positive and they range from 0.029 to 0.644. The range of the estimates is consistent with the literature using cohort-level data. For example, Attanasio and Weber (1995) show that the estimates of IES to be in the range of $0.1-$ 0.5 using 1980's data from the CE. Vissing-Jørgensen (2002) find the IES estimates to be $0.06-$ 0.5 for the overall sample using data from the 1982 - 1996 waves of the CE. On the other hand, our estimates for the LRA group are more disparate, ranging from -0.990 to 1.763. All IES estimates are positive except for the uninsured subsample (IES=-0.990).

This result suggests that households with higher risk aversion have lower IES in five domains. The five domains appear to have a common feature: they are all financial decisions and related to consumption allocation over time. For example, contributing to a pension plan involves the trade-off between scarifying today's consumption and gaining a higher level of consumption / income stream after retirement. Government jobs may not pay a wage rate as high as that in the private sector but typically provide a stable pension after retirement. The purpose of 
buying life insurance is to avoid large fluctuation in consumption in the case of a family member's death. Contrary to life insurance and pension contribution that reduces uncertainty in the future, investment in the financial market often involves risks in the form of stochastic return. Individuals who participate in the financial market may be more willing to accept a more volatile consumption path in anticipation of a higher expected return.

One outlier in our result is smoking. The health literature provides some explanation for why smoking decisions are related to intertemporal choices. Fuchs (1982) shows that health behaviors involve a trade-off between "current costs and future benefits". In the case of cigarette smoking, an individual gives up the pleasure from smoking a cigarette today in exchange for reduction in morbidities or extension of the life span. Although the trade-off is not directly measured in terms of consumption, it may reflect intertemporal choices that households consciously make.

We test the validity of our instruments to ensure that they are valid and not "weak". Studies have shown that weak instruments may cause parameter estimates highly sensitive to model specifications (Stock and Wright, 2000; Neely et al., 2001; Yogo, 2004). To detect weak instruments, we regress the real interest rate $\left(\left(1+R_{t+1}^{n}\right)\right.$ on all the instruments. It yields a $\mathrm{R}^{2}$ of 0.42 for the overall sample and remains in a similar range $(0.40-0.42)$ for the subsamples. The Sargan test for over-identification restrictions does not reject the validity of the instruments and / or model assumptions. We repeat the Sargan test for each subsample and the results are robust across subsamples (last column of Table 4).

In sum, evidence based on the IES estimates and life-cycle consumption profiles (Figure 1) suggest a negative correlation between risk aversion and IES. 


\section{Robust Analysis}

\section{VI.A. Liquidity Constraint}

In our baseline specification, the LRA groups generally show higher IES estimates than the MRA groups, but this could be because the LRA groups do not have access to the financial market and are unable to smooth their consumption. Zeldes (1989) shows that Euler equation may not hold for households facing liquidity constraints. To account for this possibility, we restrict our sample to households who have liquid assets. Liquid assets are broadly defined as investment in stocks, mutual funds, private and government bonds, and / or having a saving account and / or other financial income (including dividends, royalties, estates, or trusts). After we exclude households with liquidity constraints, $73.4 \%$ of the original sample is retained. IES estimates are shown in Table 5.

We find that for four of the seven domains, the IES for the MRA group is lower than that for the LRA group and the difference is statistically significant. The four domains are life insurance, government employment, pension contribution, and financial market participation, which are the same as the baseline results except for cigarette smoking. For non-smokers the IES becomes positive and statistically significant (IES $=0.562)$ whereas for smokers the IES becomes negative and statistically insignificant (IES $=-0.276$ ). Similar to the baseline results, most of the IES estimates are positive and statistically significant, with the exception of uninsured and government employees.

\section{VI.B. Excess sensitivity}


The permanent income hypothesis indicates that lagged income do not predict future consumption once current consumption is controlled for. Many studies have tested this hypothesis and find excess sensitivity of consumption to income, which is often interpreted as a rejection of the permanent income hypothesis. Attanasio and Weber (1995) argue that excess sensitivity may be a by-product of incorrect aggregation that ignores household preference heterogeneity and omitted variables at the household level. In this exercise, we examine the permanent income hypothesis and whether our results are robust to the inclusion of household income. As seen in Figure 1, consumption level differs between the MRA and LRA group and part of the difference may be explained by household income.

Because the $\mathrm{CE}$ does not have information on the tax paid on labor income, we use aftertax total family income instead. ${ }^{16}$ Results are shown in Table 6 (original sample) and Table 7 (for households without liquidity constraint). The risk domains that yield consistent results in both tables are life insurance, government employment, and financial market participation. When we restrict our sample to households without liquidity constraint, additional two domains (pension contribution and health insurance) also yield estimates consistent with the inverse relationship. In Table 6, the coefficient of income is not statistically significant for the MRA groups except for pension contribution, suggesting that the permanent income hypothesis holds reasonably well for the MRA group. For the LRA group, there are a few cases that the permanent income hypothesis is rejected.

\section{VI.C. Recession Effect}

\footnotetext{
${ }^{16}$ We also used before-tax labor income, but the result is very similar to the specification using after-tax family income. We only report one of them.
} 
A large recession can be seen as an unusually large shock on labor and income, which could (at least temporarily) induce households to deviate from the optimal consumption path. For example, during the Great Recession, many individuals were laid off while others had their house "underwater". In addition, banks were reluctant to extend credit to households. These financial stressful events may inflict large fluctuations in consumption due to the fall in household income and / or the constraint in borrowing channels. In this exercise, we exclude the Great Recession period (2008-2010) and repeat the estimation above. We still find that life insurance, pension contribution, and financial market participation yield IES estimates that are consistent with the inverse relationship.

\section{VI.D. Alternative Definition of Variables}

Aggregation of consumption growth within a small sample may induce measurement errors, which may cause biased estimates. Vissing-Jørgensen (2002) argues that as long as the measurement errors are multiplicative and independent of consumption, asset return, and the instruments and the time series are sufficiently long, then the estimates of IES are consistent. In the case that the time series are not long enough, the IES estimates may still be biased. Since these conditions are difficult to check, we use alternative definitions for the two domains that have small cell size and they are health insurance and alcohol drinking. There is a trade-off: a larger cell size may reduce measurement errors but may also contaminate the subsamples by including not-so-risk-averse individuals in the more risk averse pool or the other way around.

For health insurance, we define the uninsured (LRA group) as the households who have experienced uninsurance in at least one wave (16\% of the sample). This definition of uninsured includes households who were insured in some waves but uninsured in others. For alcohol, we define heavy drinkers as those who spend at least $2 \%$ of salary income on alcohol beverages 
(16\% of the sample). The estimation results are essentially unchanged from the baseline, thus they are not shown in the table. None of the two domains yield statistically significant difference between the IES estimates of the MRA and LRA group. For health insurance, we also tried other criterion to define the subsamples by dropping households whose members are ill or disabled and / or households with Medicaid insurance because enrollment in Medicaid is based mainly on eligibility and less on preference. We find very similar results as the baseline that the negative relationship between the two IES estimates is not supported based on health insurance choices. One of the possible reasons is that health insurance in the US is often provided as part of the employee benefit; hence having health insurance may not reflect individual's own choice.

\section{VI.E. Multiple Groups}

We also tested the relationship between IES among multiple groups instead of two. Because not all domains can be easily separated into more groups, we did this exercise for two domains only: cigarette smoking and pension contribution. For cigarette smoking, we define regular smokers as those who spent at least $\$ 80$ on tobacco products in each interview wave, casual smokers as those who had a positive spending in at least one interview wave, and nonsmokers who did not have any expense on tobacco products. For pension contribution, we define low contributors as those whose contribution were less than $1.75 \%$ of their before-tax income, middle contributors as those whose contribution were between $1.75 \%$ and $2.5 \%$ of their beforetax income, and high contributors as those who contributed more than $2.5 \%$.

Results are presented in Table 8. For both smoking and pension contribution, we find that the least risk averse group (regular smoker; low pension contributors) has the largest IES among the subgroups. In addition, the differences in the estimates between regular smokers and non- 
smokers, casual smokers and non-smokers are statistically significant. The differences in the estimates between low and middle contributors, low and high contributors are also statistically significant. These results are again consistent with the inverse relationship between IES and risk aversion, as we find in the baseline specification. ${ }^{17}$

\section{Conclusions and Discussions}

In this paper, we combine two streams of literature, one on risk preference and household heterogeneity and the other on life-cycle choice of consumption path, to examine whether households' risk preferences are related to their intertemporal choice in consumption. We separate our sample into two groups based on their behaviors in seven risk domains and estimate IES for each group separately in a GMM framework. IES are estimated based on an Euler equation conditional on household demographics, labor supply, and leisure time. We apply the synthetic panel approach as in Attanasio and Weber (1995).

While most of the IES estimates fall within a reasonable range found in the literature, the point estimates for the two groups differ by a large margin, with the more risk averse group generally having a lower IES estimate than the less risk averse group for majority of the domains. This is consistent with the inverse relationship of IES and risk aversion implied in the CRRA utility. Our result suggests that there exists an intuitively appealing association between intertemporal substitution and risk preference, that is, individuals who are risk averse prefer a smoother consumption path than those who are less risk averse. This is in contrast to Barsky et

\footnotetext{
17 We also experimented the three-groups case with alcohol drinking. It yielded estimates inconsistent with the CRRA utility, same as the baseline.
} 
al. (1997) that find little correlation between the two parameters using a small sample of individual-level data. ${ }^{18}$

Among the seven risk domains we examined, CRRA-consistent estimates are mostly in financial domains such as, life insurance, pension contribution, and financial market participation. Our result pertaining to financial market participation is in line with the findings in the literature of limited market participation. For example, Vissing-Jørgensen (2002) and Guvenen (2009) find that the IES for non-stockholders is lower than that for stockholders. We also find an interesting result on occupational choice: government employees prefer a smoother consumption path than non-government employees. This is consistent with the economic theory that suggests individual agents choose their job based on how they evaluate the income risk associated with jobs (Quadrini, 2000).

On the health-related domains such as buying health insurance, smoking, and heavy drinking, our results are mixed. We do not find much CRRA consistent evidence. The deviation from financial domains is consistent with the results in Dohmen et al. (2011). They find that risk measures for financial matters do not predict health decisions well. One reason could be earlylife health-related experience is different from financial-related experience, which results in different preferences and decisions later in life. For example, spending on health is likely to be driven by exogenous "health shock" such as unexpected health deterioration and accidents whereas these events may not necessarily affect financial and consumption decisions in the same

\footnotetext{
${ }^{18}$ They use individuals' response to hypothetical questions to evaluate preference and their results are based on a very small sample.
} 
way. ${ }^{19}$ In addition, government policies such as Medicaid, Medicare, and excise taxes may affect decisions in the health domain as well.

Our findings on heterogeneous preference across domains have implications for both theoretical and empirical work in the future. In many macroeconomic models, it is still conventional to assume a single risk preference parameter or a single IES parameter. Our findings suggest that this practice may be an oversimplification of the reality. As mentioned in Krusell and Smith (1998), introducing preference heterogeneity "allows a closer match between model and data". Our results may be particularly useful for studies that aim to address the implication of policy and welfare, such as income and consumption inequality. Heckman (2001) argues that in these models we need to account for both general equilibrium effect as well as heterogeneous impact of policies across different populations. Past studies on social insurance have noted that weak safety net could lead to excessive precautionary saving, which creates inefficiency in the society (Gruber and Yelowitz, 1999). Others have argued in favor of minimal intervention by the government to use transfer payments to assist households in smoothing consumption. Our study suggests that future work should explore the implication of policies across households with different risk preferences.

\section{References:}

Aguiar, Mark, Erik Hurst (2005), "Consumption vs. Expenditure," Journal of Political Economy, 113(5), 919-948

Anderson, Lisa R., Jennifer M. Mellor (2008), "Predicting Health Behaviors with an Experimental Measure of Risk Preference," Journal of Health Economics, 27, 1260-1274.

Attanasio, Orazio P., James Banks, Sarah Tanner (2002), “Asset Holding and Consumption Volatility," Journal of Political Economy, 110(4), 771-792.

\footnotetext{
${ }^{19}$ Case et al. (2002) show that experience during childhood has a long-run effect on health status of adults.
} 
Attanasio, Orazio P., Marting Browning (1995), "Consumption over the Life Cycle and over the Business Cycle,” The American Economic Review, 85(5), 1118-1137.

Attanasio, Orazio P., Guglielmo Weber (1989), “Intertemporal Substitution, Risk Aversion and the Euler Equation for Consumption,” The Economic Journal, 99, Supplement, 59-73.

Attanasio, Orazio P., Guglielmo Weber (1993), "Consumption Growth, the Interest Rate and Aggregation,” The Review of Economic Studies, 60(3), 631-649.

Attanasio, Orazio P., Guglielmo Weber (1995), "Is Consumption Growth Consistent with Intertemporal Optimization? Evidence from the Consumer Expenditure Survey," Journal of Political Economy, 103(6), 1121-1157.

Attanasio, Orazio P., Annette Vissing-Jørgensen (2003), "Stock-Market Participation, Intertemporal Substitution, and Risk-Aversion," American Economic Review, 93(2), 383-391.

Barsky, Robert B., Thomas F. Juster, Miles S Kimball, Matthew D. Shapiro (1997), "Preference Parameters and Behavioral Heterogeneity: An Experimental Approach in the Health and Retirement Study," Quarterly Journal of Economics, 112(2), 537-579.

Blundell, Richard, Martin Browning, Costas Meghir (1994), "Consumer Demand and the LifeCycle Allocation of Household Expenditures," Review of Economic Studies, 61, 57-80.

Brav, Alon, George M. Constantinides, Christopher C. Geczy (2002), “Asset Pricing with Heterogeneous Consumers and Limited Participation: Empirical Evidence," Journal of Political Economy, 110(4), 793-824.

Campbell, John Y. (1996), "Understanding Risk and Return,” Journal of Political Economy, 104(2), 298-345.

Case, Anne, Darren Lubotsky, Christina Paxson (2002), "Economic Status and Health in Childhood: The Origins of the Gradient," American Economic Review, 92(5), 1308-1334.

Chamberlain, Gary (1984), "Panel Data," in Handbook of Econometrics, 2, edited by Zvi Griliches and Michael D. Intriligator, Amsterdam: North-Holland.

Cogley, Timothy (2002), "Idiosyncratic Risk and the Equity Premium: Evidence from the Consumer Expenditure Survey," Journal of Monetary Economics, 49, 309-334.

Cutler, David M., Amy Finkelstein, and Kathleen McGarry (2008), "Preference Heterogeneity and Insurance Markets: Explaining a puzzle of insurance", American Economic Review, 98(2), 157-162. 
Dohmen, Thomas, Armn Falk, David Huffman, Uwe Sunde, Juergen Schupp, Gert G. Wagner (2011), "Individual Risk Attitudes: Measurement, Determinants and Behavioral Consequences," Journal of the European Economic Association 9(3), 522-550.

Einav, Liran, Amy Finkelstein, Iuliana Pascu, and Mark R. Cullen (2012), "How General are Risk Preferences? Choices Under Uncertainty in Different Domains," American Economic Review, 102(6), 2606-2638.

Epstein, Larry G., Stanley E. Zin (1989), "Substitution, Risk Aversion, and the Temporal Behavior of Consumption and Asset Returns. I: A Theoretical Framework," Econometrica, 57, 937-970.

Fernandez-Villaverde, Jesus, Dirk Krueger (2007), "Consumption over the Life cycle: Facts from Consumer Expenditure Survey Data," Review of Economics and Statistics, 89(3), 552-565.

Fuchs, (1982) "Time Preference and Health: An Exploratory Study", Economic Aspects of Health, edited by Victor R. Fuchs, pp. 93-120. Chicago: University of Chicago Press.

Gruber, Jonathan, Aaron Yelowitz (1999), "Public Health Insurance and Private Savings," Journal of Political Economy, 107(6), 1249-1274.

Guvenen, Fatih (2009), "A Parsimonious Macroeconomic Model for Asset Pricing," Econometrica, 77(6), 1711-1750.

Hall, Robert E (1978), "Stochastic Implications of the Life Cycle-Permanent Income Hypothesis: Theory and Evidence," Journal of Political Economy, 86(6), 971-87.

Hall, Robert E. (1988), "Intertemporal Substitution in Consumption," Journal of Political Economy, 96(2), 339-357.

Hansen, Lars P, Kenneth J. Singleton (1983), "Stochastic Consumption, Risk Aversion, and the Temporal Behavior of Asset Returns," Journal of Political Economy, 91, 249-265.

Hansen, Lars P, Kenneth J. Singleton (1996), "Efficient Estimation of Linear Asset Pricing Models With Moving Average Errors," Journal of Business \& Economic Statistics, 14, 53-68.

Hayashi, Fumio (1987), "Tests for Liquidity Constraints: A Critical Survey and Some New Results," in Advances in Econometrics Fifth World Congress, 2, edited by Truman F. Bewley, Amsterdam: North-Holland (for Econometric Soc.)

Heathcote, Jonathan, Kjetil Storesletten, Giovanni L. Violante (2009), "Quantitative Macroeconomics with Heterogeneous Households," Annual Review of Economics, Annual Reviews, 1(1): 319-354, 05.

Heckman, James J. (2001), "Micro data, heterogeneity, and the evaluation of public policy: Nobel lecture", Journal of Political Economy, 109(4):673-748. 
Jones, Larry E., Rodolfo Manuelli, Henry Siu (2000), “Growth and Business Cycles,” NBER Working Paper no. 7633, Cambridge, Mass.

Kimball, Miles S. (1993), “Standard Risk Aversion,” Econometrica, 61(3), 589-611.

King, Robert G., Sergio Rebelo (1990), "Public Policy and Economic Growth: Developing Neoclassical Implications," Journal of Political Economy, 98(5), S127-S150.

Krusell, Per, Anthony A. Smith (1998), "Income and Wealth Heterogeneity in the Macroeconomy," Journal of Political Economy, 106(5), 867-896.

Neely, Christopher J., Amlan Roy, Charles H. Whiteman (2001), "Risk Aversion versus Intertemporal Substitution: A Case Study of Identification Failure in the Intertemporal Consumption Capital Asset Pricing Model," Journal of Business \& Economic Statistics, 19(4), 395-403.

Ogaki, Masao, Carmen M. Reinhart (1998), "Measuring Intertemporal Substitution: The Role of Durable Goods," Journal of Political Economy, 106(5), 1078-1098.

Quadrini, Vincenzo, (2000), "Entrepreneurship, saving and social mobility", Review of Economic Dynamics, 3(1):1-40.

Schulhofer-Wohl, Sam (2008), "Heterogeneous Risk Preferences and the Welfare Cost of Business Cycles," Review of Economics Dynamics, 11, 761-780.

Stock, James H., Jonathan H. Wright (2000), "GMM with Weak Identification," Econometrica, 68(5), 1055-1096.

Swanson, Eric T. (2012), "Risk Aversion and the Labor Margin in Dynamic Equilibrium Models," American Economic Review, 102(4), 1663-1691.

Vissing-Jørgensen, Annette (2002), "Limited Asset Market Participation and the Elasticity of Intertemporal Substitution," Journal of Political Economy, 110(4), 825-853.

Yogo, Motohiro (2004), "Estimating the Elasticity of Intertemporal Substitution when Instruments are Weak," Review of Economics and Statistics, 86(3), 797-810.

Zeldes, Stephen P. (1989), "Consumption and Liquidity Constraints: An Empirical Investigation," Journal of Political Economy, 97(2), 305-346. 
Table 1 Summary statistics by risk domain, CEX, 1996 - 2010

\begin{tabular}{|c|c|c|c|c|c|}
\hline Domain & $\begin{array}{l}\text { Group by risk } \\
\text { attitude }\end{array}$ & Definition & $\begin{array}{l}\text { Percent } \\
\text { of the } \\
\text { overall } \\
\text { sample }\end{array}$ & $\begin{array}{l}\text { Mean and. st. } \\
\text { dev. of cons. } \\
\text { growth }\end{array}$ & $\begin{array}{l}\text { Average cell } \\
\text { size (cohort } \\
\text { min, cohort } \\
\max )\end{array}$ \\
\hline \multirow[t]{2}{*}{$\begin{array}{l}\text { Health } \\
\text { insurance }\end{array}$} & Insured & $\begin{array}{l}\text { Have insurance in current } \\
\text { interview }\end{array}$ & 0.88 & $\begin{array}{l}-0.008 \\
(0.044)\end{array}$ & $\begin{array}{c}428 \\
(333,491)\end{array}$ \\
\hline & Uninsured & $\begin{array}{l}\text { Without health insurance in } \\
\text { current interview }\end{array}$ & 0.12 & $\begin{array}{l}-0.018 \\
(0.081)\end{array}$ & $\begin{array}{c}58 \\
(40,67)\end{array}$ \\
\hline \multirow[t]{2}{*}{$\begin{array}{l}\text { Life } \\
\text { insurance }\end{array}$} & $\begin{array}{l}\text { With life } \\
\text { insurance }\end{array}$ & $\begin{array}{l}\text { Report life insurance in all } \\
\text { interview waves }\end{array}$ & 0.60 & $\begin{array}{l}-0.009 \\
(0.052)\end{array}$ & $\begin{array}{c}293 \\
(188,356)\end{array}$ \\
\hline & $\begin{array}{l}\text { Without life } \\
\text { insurance }\end{array}$ & $\begin{array}{l}\text { Do not have life insurance in } \\
\text { all waves }\end{array}$ & 0.40 & $\begin{array}{l}-0.009 \\
(0.051)\end{array}$ & $\begin{array}{c}194 \\
(146,218)\end{array}$ \\
\hline \multirow[t]{2}{*}{$\begin{array}{l}\text { Cigarette } \\
\text { Smoking }\end{array}$} & Non-smokers & $\begin{array}{l}\text { No positive smoking expense } \\
\text { in any wave }\end{array}$ & 0.64 & $\begin{array}{l}-0.007 \\
(0.048)\end{array}$ & $\begin{array}{c}312 \\
(261,343)\end{array}$ \\
\hline & Smokers & $\begin{array}{l}\text { With positive smoking } \\
\text { expense in at least one wave }\end{array}$ & 0.36 & $\begin{array}{l}-0.013 \\
(0.054)\end{array}$ & $\begin{array}{c}175 \\
(133,214)\end{array}$ \\
\hline \multirow[t]{2}{*}{$\begin{array}{l}\text { Alcohol } \\
\text { drinking }\end{array}$} & $\begin{array}{l}\text { Non-heavy } \\
\text { drinkers }\end{array}$ & $\begin{array}{l}\text { No spending over } \$ 100 \text { in all } \\
\text { interview waves }\end{array}$ & 0.86 & $\begin{array}{l}-0.010 \\
(0.043)\end{array}$ & $\begin{array}{c}418 \\
(338,474)\end{array}$ \\
\hline & $\begin{array}{l}\text { Heavy } \\
\text { drinkers }\end{array}$ & $\begin{array}{l}\text { Alcohol expenditure }>\$ 100 \text { in } \\
\text { all interview waves }\end{array}$ & 0.14 & $\begin{array}{l}-0.008 \\
(0.076)\end{array}$ & $\begin{array}{c}68 \\
(55,81)\end{array}$ \\
\hline \multirow[t]{2}{*}{$\begin{array}{l}\text { Government } \\
\text { job }\end{array}$} & $\begin{array}{l}\text { Government } \\
\text { employees }\end{array}$ & $\begin{array}{l}\text { Any household member } \\
\text { employed in federal, state, and } \\
\text { local government }\end{array}$ & 0.21 & $\begin{array}{l}-0.010 \\
(0.042)\end{array}$ & $\begin{array}{c}102 \\
(70,124)\end{array}$ \\
\hline & $\begin{array}{l}\text { Non } \\
\text { government } \\
\text { employees }\end{array}$ & Not employed in government & 0.79 & $\begin{array}{l}-0.009 \\
(0.073)\end{array}$ & $\begin{array}{c}384 \\
(324,437)\end{array}$ \\
\hline \multirow[t]{2}{*}{$\begin{array}{l}\text { Retirement } \\
\text { contr. }\end{array}$} & $\begin{array}{l}\text { High pension } \\
\text { contributors }\end{array}$ & $\begin{array}{l}\text { Contribution in the past } 3 \\
\text { months before interview }>2 \% \\
\text { before-tax income, including } \\
\text { retirement funds, pensions, } \\
\text { and social security }\end{array}$ & 0.33 & $\begin{array}{l}-0.010 \\
(0.062)\end{array}$ & $\begin{array}{c}162 \\
(110,197)\end{array}$ \\
\hline & $\begin{array}{l}\text { Low pension } \\
\text { contributors }\end{array}$ & $\begin{array}{l}\text { Contribution }<=2 \% \text { before-tax } \\
\text { income }\end{array}$ & 0.67 & $\begin{array}{l}-0.009 \\
(0.043)\end{array}$ & $\begin{array}{c}325 \\
(283,361)\end{array}$ \\
\hline \multirow[t]{2}{*}{$\begin{array}{l}\text { Financial } \\
\text { market } \\
\text { participation }\end{array}$} & Participants & $\begin{array}{l}\text { Positive holdings in securities } \\
\text { (such as, stocks, mutual fund, } \\
\text { private bond, treasury notes) } \\
\text { (only avail. in wave 5) }\end{array}$ & 0.16 & $\begin{array}{l}-0.012 \\
(0.042)\end{array}$ & $\begin{array}{c}77 \\
(40,93)\end{array}$ \\
\hline & $\begin{array}{l}\text { Non- } \\
\text { participants }\end{array}$ & No holdings in securities & 0.84 & $\begin{array}{c}0.004 \\
(0.086)\end{array}$ & $\begin{array}{c}410 \\
(349,462)\end{array}$ \\
\hline
\end{tabular}

Note: Sample period is from 1996Q1-2010Q4. Sample size $=178,074$. Average cell size refers to the average number of observations per cohort per quarter. Cohort min reports the smallest cell size among the six cohorts. Cohort max reports the largest cell size among the six cohorts. Mean and standard deviation of consumption growth for each subsample is seasonally adjusted. That is, we regress the sample mean of each group on 12 monthly dummies and obtain the residuals. We then add the residuals to the original sample mean. 
Table 2 Summary statistics by cohort

\begin{tabular}{|c|c|c|c|c|c|c|}
\hline Cohort & $1946-1950$ & 1951-1955 & $1956-1960$ & $1961-1965$ & $1966-1970$ & $1971-1975$ \\
\hline Age in 1996 & $46-50$ & $41-45$ & $36-40$ & $31-35$ & $26-30$ & $21-25$ \\
\hline Uninsured & 0.09 & 0.11 & 0.12 & 0.12 & 0.13 & 0.15 \\
\hline $\begin{array}{l}\text { Without life } \\
\text { insurance }\end{array}$ & 0.33 & 0.35 & 0.36 & 0.40 & 0.46 & 0.52 \\
\hline Smokers & 0.36 & 0.37 & 0.38 & 0.37 & 0.33 & 0.34 \\
\hline Heavy drinkers & 0.14 & 0.14 & 0.15 & 0.14 & 0.14 & 0.14 \\
\hline $\begin{array}{l}\text { Non government } \\
\text { employees } \\
\text { Low pension } \\
\text { contributors }\end{array}$ & 0.66 & 0.64 & 0.65 & 0.66 & 0.69 & $\begin{array}{l}0.82 \\
0.72\end{array}$ \\
\hline $\begin{array}{l}\text { Financial market } \\
\text { participants }\end{array}$ & 0.20 & 0.18 & 0.17 & 0.16 & 0.13 & 0.10 \\
\hline $\begin{array}{l}\text { Nondurable } \\
\text { consumption } \\
\text { (quarterly) }\end{array}$ & 4606.63 & 4719.38 & 4903.04 & 4797.17 & 4546.83 & 4192.31 \\
\hline Family size & 2.34 & 2.67 & 3.03 & 3.25 & 3.25 & 3.02 \\
\hline Single status & 0.26 & 0.22 & 0.18 & 0.17 & 0.17 & 0.21 \\
\hline Wife leisure & 95.50 & 94.03 & 94.04 & 94.68 & 95.04 & 96.69 \\
\hline Wife fulltime & 0.28 & 0.32 & 0.32 & 0.30 & 0.30 & 0.27 \\
\hline $\begin{array}{l}\text { Number of } \\
\text { children }\end{array}$ & 0.31 & 0.60 & 0.98 & 1.31 & 1.40 & 1.23 \\
\hline $\begin{array}{l}\text { Household } \\
\text { salary income }\end{array}$ & $54,869.39$ & $60,943.47$ & $62,963.58$ & $61,636.18$ & $58,861.08$ & $52,843.40$ \\
\hline $\begin{array}{l}\text { Household } \\
\text { before-tax } \\
\text { income }\end{array}$ & 67640.53 & 70482.38 & $70,855.90$ & $67,906.68$ & $64,272.25$ & $56,924.22$ \\
\hline
\end{tabular}

Note: wife's leisure is measured out of 112 hours per week. Wife fulltime $=1$ if wife works greater than or equal to 40 hours per week. 
Table 3 Spearman correlations of risk measures

\begin{tabular}{|c|c|c|c|c|c|c|c|}
\hline & Uninsured & $\begin{array}{l}\text { Without } \\
\text { life } \\
\text { insurance }\end{array}$ & Smokers & $\begin{array}{l}\text { Heavy } \\
\text { drinkers }\end{array}$ & $\begin{array}{l}\text { Non } \\
\text { government } \\
\text { employees }\end{array}$ & $\begin{array}{l}\text { Low } \\
\text { pension } \\
\text { contributors }\end{array}$ & $\begin{array}{l}\text { Security } \\
\text { holders }\end{array}$ \\
\hline Uninsured & 1 & & & & & & \\
\hline $\begin{array}{l}\text { Without life } \\
\text { insurance }\end{array}$ & $\begin{array}{l}0.266^{*} \\
(0.000)\end{array}$ & 1 & & & & & \\
\hline Smokers & $\begin{array}{l}0.041^{*} \\
(0.000)\end{array}$ & $\begin{array}{l}0.051^{*} \\
(0.000)\end{array}$ & 1 & & & & \\
\hline $\begin{array}{l}\text { Heavy } \\
\text { drinkers }\end{array}$ & $\begin{array}{c}-0.054 * \\
(0.000)\end{array}$ & $\begin{array}{c}-0.086^{*} \\
(0.000)\end{array}$ & $\begin{array}{l}0.075^{*} \\
(0.000)\end{array}$ & 1 & & & \\
\hline $\begin{array}{l}\text { Non } \\
\text { government } \\
\text { employees }\end{array}$ & $\begin{array}{l}0.117^{*} \\
(0.000)\end{array}$ & $\begin{array}{l}0.165^{*} \\
(0.000)\end{array}$ & $\begin{array}{l}0.073 * \\
(0.000)\end{array}$ & $\begin{array}{l}-0.003 \\
(0.213)\end{array}$ & 1 & & \\
\hline $\begin{array}{l}\text { Low } \\
\text { pension } \\
\text { contributors }\end{array}$ & $\begin{array}{l}0.114^{*} \\
(0.000)\end{array}$ & $\begin{array}{l}0.218^{*} \\
(0.000)\end{array}$ & $\begin{array}{l}0.055^{*} \\
(0.000)\end{array}$ & $\begin{array}{c}-0.116^{*} \\
(0.000)\end{array}$ & $\begin{array}{l}0.145^{*} \\
(0.000)\end{array}$ & 1 & \\
\hline $\begin{array}{l}\text { Financial } \\
\text { market } \\
\text { participants }\end{array}$ & $\begin{array}{c}-0.108^{*} \\
(0.000)\end{array}$ & $\begin{array}{c}-0.183^{*} \\
(0.000)\end{array}$ & $\begin{array}{c}-0.067^{*} \\
(0.000)\end{array}$ & $\begin{array}{l}0.141^{*} \\
(0.000)\end{array}$ & $\begin{array}{c}-0.061 * \\
(0.000)\end{array}$ & $\begin{array}{c}-0.219^{*} \\
(0.000)\end{array}$ & 1 \\
\hline
\end{tabular}

Note: * means the correlation coefficient is statistically significantly different from zero at the 5\% significant level. P-values are included in the parentheses. 
Table 4 IES estimates by risk domains: baseline specification

\begin{tabular}{l|cccc}
\hline \multicolumn{1}{c|}{\begin{tabular}{c} 
Risk Domain \\
\multicolumn{1}{c|}{ (MRA / LRA) }
\end{tabular}} & $\begin{array}{c}\text { IES } \\
\text { (st. error) }\end{array}$ & $\begin{array}{c}I E S_{L R A} \\
\text { (st. error) }\end{array}$ & $\begin{array}{c}\text { Hypo Test } \\
\mathrm{H}_{0}: I E S_{M R A} \\
-I E S_{L R A} \geq 0 \\
\text { (p-value) }\end{array}$ & $\begin{array}{l}\text { Hansen's J } \\
\text { (p-value) }\end{array}$ \\
\hline Health insurance & $0.644^{* * *}$ & $-0.990^{* * *}$ & 1.634 & 18.00 \\
(insured / uninsured) & $(0.142)$ & $(0.338)$ & $(0.999)$ & $(1.000)$ \\
Life insurance & $0.441^{* *}$ & $0.816^{* * *}$ & $-0.375^{* *}$ & 20.83 \\
(insured / uninsured) & $(0.172)$ & $(0.135)$ & $(0.047)$ & $(1.000)$ \\
Cigarette smoking & 0.053 & $0.915^{* * *}$ & $-0.861 * * *$ & 20.24 \\
(nonsmokers / smokers) & $(0.185)$ & $(0.118)$ & $(0.000)$ & $(1.000)$ \\
Heavy Alcohol drinking & $0.571 * * *$ & -0.166 & 0.737 & 20.46 \\
(nondrinkers / drinkers) & $(0.094)$ & $(0.234)$ & $(0.999)$ & $(1.000)$ \\
Govt. employment & 0.169 & $0.661 * * *$ & $-0.492^{* *}$ & 23.24 \\
(empl. / not empl.) & $(0.715)$ & $(0.087)$ & $(0.036)$ & $(0.999)$ \\
Pension contribution & 0.029 & $0.344 *$ & $-0.315^{* *}$ & 29.95 \\
(high / low) & $(0.191)$ & $(0.188)$ & $(0.035)$ & $(0.994)$ \\
Financial market & $0.358^{* *}$ & $1.763 * * *$ & $-1.405^{* * *}$ & 16.43 \\
participation (no & $(0.176)$ & $(0.295)$ & $(0.002)$ & $(1.000)$ \\
particip. / particip.) & & & & \\
\hline
\end{tabular}

Note: $* * * * *, *$ indicate statistical significance at $1 \%, 5 \%$, and $10 \%$, respectively. Sample size $=336$. MRA stands for more risk averse and LRA stands for less risk averse. Hypothesis test in the third column of numbers is a one-sided test with $\mathrm{H}_{0}$ : IES $S_{M R A}-I E S_{L R A} \geq 0$. Household demographic variables (family size, single, wives' leisure and full-time status, number of children under 18) are included in all estimations. 
Table 5 IES estimates: households without liquidity constraint

\begin{tabular}{l|cccc}
\hline \multicolumn{1}{c|}{$\begin{array}{l}\text { Risk Domain } \\
\text { (MRA / LRA) }\end{array}$} & $\begin{array}{c}\text { IES } \\
\text { (st. error) }\end{array}$ & $\begin{array}{c}I E S_{L R A} \\
\text { (st. error) }\end{array}$ & $\begin{array}{c}\text { Hypo Test } \\
\mathrm{H}_{0}: I E S_{M R A} \\
-I E S_{L R A} \geq 0 \\
(\mathrm{p} \text {-value) }\end{array}$ & $\begin{array}{c}\text { Hansen's J } \\
\text { (p-value) }\end{array}$ \\
\hline Health insurance & $0.333^{* * *}$ & $-2.152^{* * *}$ & 2.485 & 22.13 \\
(insured / uninsured) & $(0.107)$ & $(0.545)$ & $(0.999)$ & $(0.999)$ \\
Life insurance & 0.078 & $0.703^{* * *}$ & $-0.625^{* * *}$ & 27.28 \\
(insured / uninsured) & $(0.137)$ & $(0.223)$ & $(0.009)$ & $(0.998)$ \\
Cigarette smoking & $0.562^{* * *}$ & -0.276 & 0.839 & 24.90 \\
(nonsmokers / smokers) & $(0.134)$ & $(0.370)$ & $(0.992)$ & $0.999)$ \\
Heavy Alcohol drinking & $0.537^{* *}$ & 0.130 & 0.406 & 21.86 \\
(nondrinkers / drinkers) & $(0.239)$ & $(0.324)$ & $(0.862)$ & $(0.999)$ \\
Govt. employment & $-0.749^{* * *}$ & $0.253^{* *}$ & $-1.001 * *$ & 30.00 \\
(empl. / not empl.) & $(0.274)$ & $(0.127)$ & $(0.0003)$ & $(0.994)$ \\
Pension contribution & -0.315 & $0.735^{* * *}$ & $-1.050^{* * *}$ & 30.21 \\
(high / low) & $(0.201)$ & $(0.107)$ & $(0.000)$ & $(0.993)$ \\
Fin. market participation & $0.323^{* * *}$ & $1.737^{* * *}$ & $-1.414 * *$ & 18.85 \\
(no particip. / particip.) & $(0.079)$ & $(0.653)$ & $(0.021)$ & $(1.000)$ \\
\hline
\end{tabular}

Note: $* * *, * * *$ indicate statistical significance at $1 \%, 5 \%$, and $10 \%$, respectively. Sample size $=336$. MRA stands for more risk averse and LRA stands for less risk averse. Hypothesis test in the third column of numbers is a onesided test with $\mathrm{H}_{0}: I E S_{M R A}-I E S_{L R A} \geq 0$. Household demographic variables (family size, single, wives' leisure and full-time status, number of children under 18) are included in all estimations. Households without liquidity constraints are defined as those with positive financial assets (stock, saving account, and financial income), and those who own a house. This is $73.4 \%$ of the original sample. 
Table 6 IES estimates: including family income as additional variable

\begin{tabular}{|c|c|c|c|c|c|c|}
\hline \multirow{2}{*}{$\begin{array}{l}\text { Risk Domain } \\
\text { (MRA / LRA) }\end{array}$} & \multirow{2}{*}{$\begin{array}{c}I E S_{M R A} \\
\text { (st. } \\
\text { error) }\end{array}$} & \multirow{2}{*}{$\begin{array}{l}I E S_{L R A} \\
\quad \text { (st. } \\
\text { error) }\end{array}$} & \multirow{2}{*}{$\begin{array}{l}\text { Hypo Test } \\
\mathrm{H}_{0}: I E S_{M R A} \\
-I E S_{L R A} \geq 0 \\
\text { (p-value) }\end{array}$} & \multirow{2}{*}{$\begin{array}{l}\text { Hansen's J } \\
\text { (p-value) }\end{array}$} & \multicolumn{2}{|c|}{ Income significant? } \\
\hline & & & & & MRA & LRA \\
\hline $\begin{array}{l}\text { Health insurance } \\
\text { (insured / uninsured) }\end{array}$ & $\begin{array}{l}0.695^{* * *} \\
(0.096)\end{array}$ & $\begin{array}{l}-0.359 \\
(0.339)\end{array}$ & $\begin{array}{c}1.050 \\
(0.998)\end{array}$ & $\begin{array}{l}16.60 \\
(1.000)\end{array}$ & $\begin{array}{l}-0.062 \\
(0.577)\end{array}$ & $\begin{array}{l}1.252^{*} \\
(0.703)\end{array}$ \\
\hline $\begin{array}{l}\text { Life insurance } \\
\text { (insured / uninsured) }\end{array}$ & $\begin{array}{c}0.370 \\
(0.121)\end{array}$ & $\begin{array}{c}0.909 * * * \\
(0.160)\end{array}$ & $\begin{array}{c}-0.539 * * * \\
(0.005)\end{array}$ & $\begin{array}{c}21.13 \\
(0.999)\end{array}$ & $\begin{array}{l}-0.387 \\
(0.772)\end{array}$ & $\begin{array}{l}-0.013 \\
(0.245)\end{array}$ \\
\hline $\begin{array}{l}\text { Cigarette smoking } \\
\text { (nonsmokers / smokers) }\end{array}$ & $\begin{array}{c}0.172 \\
(0.351)\end{array}$ & $\begin{array}{c}0.285 \\
(0.308)\end{array}$ & $\begin{array}{l}-0.113 \\
(0.425)\end{array}$ & $\begin{array}{c}20.27 \\
(1.000)\end{array}$ & $\begin{array}{l}-0.073 \\
(1.306)\end{array}$ & $\begin{array}{l}-0.828^{*} \\
(0.479)\end{array}$ \\
\hline $\begin{array}{l}\text { Heavy Alcohol drinking } \\
\text { (nondrinkers / drinkers) }\end{array}$ & $\begin{array}{c}0.559^{* * *} \\
(0.135)\end{array}$ & $\begin{array}{l}-0.268 \\
(0.232)\end{array}$ & $\begin{array}{c}0.827 \\
(0.999)\end{array}$ & $\begin{array}{c}18.28 \\
(1.000)\end{array}$ & $\begin{array}{l}-0.080 \\
(0.400)\end{array}$ & $\begin{array}{c}0.405 \\
(0.311)\end{array}$ \\
\hline $\begin{array}{l}\text { Govt. employment } \\
\text { (empl. / not empl.) }\end{array}$ & $\begin{array}{c}0.146 \\
(0.215)\end{array}$ & $\begin{array}{c}0.512 * * * \\
(0.116)\end{array}$ & $\begin{array}{c}-0.367 * * \\
(0.042)\end{array}$ & $\begin{array}{c}22.34 \\
(0.999)\end{array}$ & $\begin{array}{c}0.433 \\
(0.400)\end{array}$ & $\begin{array}{c}-1.196^{* * *} \\
(0.324)\end{array}$ \\
\hline $\begin{array}{l}\text { Pension contribution } \\
\text { (high / low) }\end{array}$ & $\begin{array}{l}-0.023 \\
(0.229)\end{array}$ & $\begin{array}{c}0.243 \\
(0.194)\end{array}$ & $\begin{array}{l}-0.266 \\
(0.103)\end{array}$ & $\begin{array}{c}23.04 \\
(0.999)\end{array}$ & $\begin{array}{r}1.157^{* *} \\
(0.521)\end{array}$ & $\begin{array}{c}1.012 * * * \\
(0.389)\end{array}$ \\
\hline $\begin{array}{l}\text { Stock market participation } \\
\text { (no particip. / particip.) }\end{array}$ & $\begin{array}{l}0.327^{* *} \\
(0.142)\end{array}$ & $\begin{array}{c}1.412 * * * \\
(0.207)\end{array}$ & $\begin{array}{c}-1.085^{* * *} \\
(0.000)\end{array}$ & $\begin{array}{c}18.43 \\
(1.000)\end{array}$ & $\begin{array}{l}-0.068 \\
(0.212)\end{array}$ & $\begin{array}{l}-0.507 \\
(0.479)\end{array}$ \\
\hline
\end{tabular}

Note: $* * *, * * *$ indicate statistical significance at $1 \%, 5 \%$, and $10 \%$, respectively. Sample size $=336$. MRA stands for more risk averse and LRA stands for less risk averse. Hypothesis test in the third column of numbers is a onesided test with $\mathrm{H}_{0}$ : IES $S_{M R A}$ - IES $S_{L R A} \geq 0$. Household demographic variables (family size, single, wives' leisure and full-time status, number of children under 18) are included in all estimations. 
Table 7 IES estimates: including family income as additional variable and excluding households with liquidity constraints

\begin{tabular}{l|cccccc}
\hline \multirow{2}{*}{$\begin{array}{l}\text { Risk Domain } \\
\text { (MRA / LRA) }\end{array}$} & IES & & Hypo Test \\
& & $I E S_{L R A}$ & $\begin{array}{l}\mathrm{H}_{0}: I E S_{M R A} \\
-I E S_{L R A} \geq 0\end{array}$ & Hansen's J & Income significant? \\
& (st. error) & (st. error) & (p-value) & (p-value) & MRA & LRA \\
\hline Health insurance & $0.531^{* * *}$ & $0.936^{* * *}$ & $-0.404^{* *}$ & 17.53 & -1.080 & $2.766^{* * *}$ \\
& $(0.186)$ & $(0.010)$ & $(0.011)$ & $(1.000)$ & $(0.84)$ & $(0.513)$ \\
Life insurance & 0.071 & $0.642^{* *}$ & $-0.571^{* *}$ & 23.06 & $-1.317^{* *}$ & $1.179 * *$ \\
Cigarette & $(0.231)$ & $(0.294)$ & $(0.038)$ & $(0.999)$ & $(0.606)$ & $(0.334)$ \\
smoking & $0.884^{* * *}$ & -0.254 & 1.138 & 18.84 & $1.274 * * *$ & $-0.901^{* *}$ \\
Alcohol drinking & $(0.121)$ & $(0.271)$ & $(0.999)$ & $(1.000)$ & $(0.359)$ & $(0.420)$ \\
Govt. & $0.706^{* * *}$ & 0.304 & 0.402 & 22.84 & 0.256 & 0.545 \\
employment & $(0.191)$ & $(0.249)$ & $(0.901)$ & $(0.999)$ & $(0.562)$ & $(0.431)$ \\
Pension & $-0.680^{* * *}$ & 0.197 & $-0.877^{* * *}$ & 28.92 & 0.541 & $-2.452^{* *}$ \\
contribution & $(0.244)$ & $(0.186)$ & $(0.0006)$ & $(0.993)$ & $(0.729)$ & $(0.942)$ \\
Stock market & 0.178 & $0.824^{* * *}$ & $-0.645^{* * *}$ & 22.85 & $1.549 * *$ & 0.365 \\
participation & $(0.190)$ & $(0.137)$ & $(0.003)$ & $(0.999)$ & $(0.528)$ & $(0.499)$ \\
\hline
\end{tabular}

Note: $* * *, * * *$ indicate statistical significance at $1 \%, 5 \%$, and $10 \%$, respectively. Sample size $=336$. MRA stands for more risk averse and LRA stands for less risk averse. Hypothesis test in the third column of numbers is a onesided test with $\mathrm{H}_{0}: I E S_{M R A}-I E S_{L R A} \geq 0$. Household demographic variables (family size, single, wives' leisure and full-time status, number of children under 18) are included in all estimations. Households without liquidity constraints are defined as those with positive financial assets (stock, saving account, and financial income), and those who own a house. 
Table 8 IES estimates with multiple groups

\begin{tabular}{|c|c|c|c|c|c|c|}
\hline Groups & Definition & Percentage & $\begin{array}{c}I E S \\
\text { (st. error) }\end{array}$ & $\begin{array}{l}\mathrm{H}_{0}: I E S_{3} \\
-I E S_{1} \geq 0 \\
\text { (p-value) }\end{array}$ & $\begin{array}{c}\mathrm{H}_{0}: I E S_{2} \\
-I E S_{1} \geq 0 \\
\text { (p-value) }\end{array}$ & $\begin{array}{l}\mathrm{H}_{0}: I E S_{3} \\
-I E S_{2} \geq 0 \\
\text { (p-value) }\end{array}$ \\
\hline \multicolumn{7}{|l|}{$\begin{array}{l}\text { Cigarette } \\
\text { smoking }\end{array}$} \\
\hline $\begin{array}{l}\text { 1.Regular } \\
\text { smoker }\end{array}$ & $\begin{array}{l}\text { Smoking } \\
\text { expense over } \\
\$ 70 \text { in all } \\
\text { interview waves }\end{array}$ & $17.73 \%$ & $\begin{array}{l}0.843 * * * \\
(0.222)\end{array}$ & $\begin{array}{l}-0.493 * * \\
(0.019)\end{array}$ & & \\
\hline $\begin{array}{l}\text { 2.Casual } \\
\text { smoker }\end{array}$ & $\begin{array}{l}\text { Positive expense } \\
\text { in at least one } \\
\text { wave }\end{array}$ & $18.24 \%$ & $\begin{array}{l}0.688 * * * \\
(0.155)\end{array}$ & & $\begin{array}{l}-0.155 \\
(0.250)\end{array}$ & \\
\hline 3.Non-smoker & $\begin{array}{l}\text { No smoking } \\
\text { expense in any } \\
\text { wave }\end{array}$ & $64.03 \%$ & $\begin{array}{l}0.351 * * \\
(0.135)\end{array}$ & & & $\begin{array}{l}-0.337^{*} \\
(0.074)\end{array}$ \\
\hline \multicolumn{7}{|l|}{$\begin{array}{l}\text { Retirement } \\
\text { Contr. }\end{array}$} \\
\hline $\begin{array}{l}\text { 1. low } \\
\text { contributors }\end{array}$ & $\begin{array}{l}\text { Contribution } \\
<=1.75 \% \text { before- } \\
\text { tax income }\end{array}$ & $23.76 \%$ & $\begin{array}{l}0.893 * * * \\
(0.188)\end{array}$ & $\begin{array}{l}-0.535^{* *} \\
(0.024)\end{array}$ & & \\
\hline $\begin{array}{l}\text { 2. middle } \\
\text { contributors }\end{array}$ & $\begin{array}{l}\text { Contribution } \\
\text { between } 1.75 \% \\
\text { and } 2.5 \%\end{array}$ & $50.90 \%$ & $\begin{array}{l}0.313^{* *} \\
(0.148)\end{array}$ & & $\begin{array}{l}-0.580^{* *} \\
(0.023)\end{array}$ & \\
\hline $\begin{array}{l}\text { 3. high } \\
\text { contributors }\end{array}$ & $\begin{array}{l}\text { Contribution } \\
>2.5 \%\end{array}$ & $25.31 \%$ & $\begin{array}{l}0.359 * * \\
(0.177)\end{array}$ & & & $\begin{array}{l}0.045 \\
(0.646)\end{array}$ \\
\hline
\end{tabular}

Note: ***,**, indicate statistical significance at $1 \%, 5 \%$, and $10 \%$, respectively. Sample size $=336$. Group 1 is the least risk averse and group 3 is the most risk averse group. In the last three columns, one-sided tests and the p-values in parentheses are shown. Household demographic variables (family size, single, wives' leisure and full-time status, number of children under 18) are included in all estimations. Hansen's J test statistics for cigarette smoking is 34.90 ( $\mathrm{p}$-value = $1.000)$ and for retirement contribution is 35.48 ( $\mathrm{p}$-value $=1.000)$. 


\section{Figure 1 Life-cylce Consumption by Risk Preference}
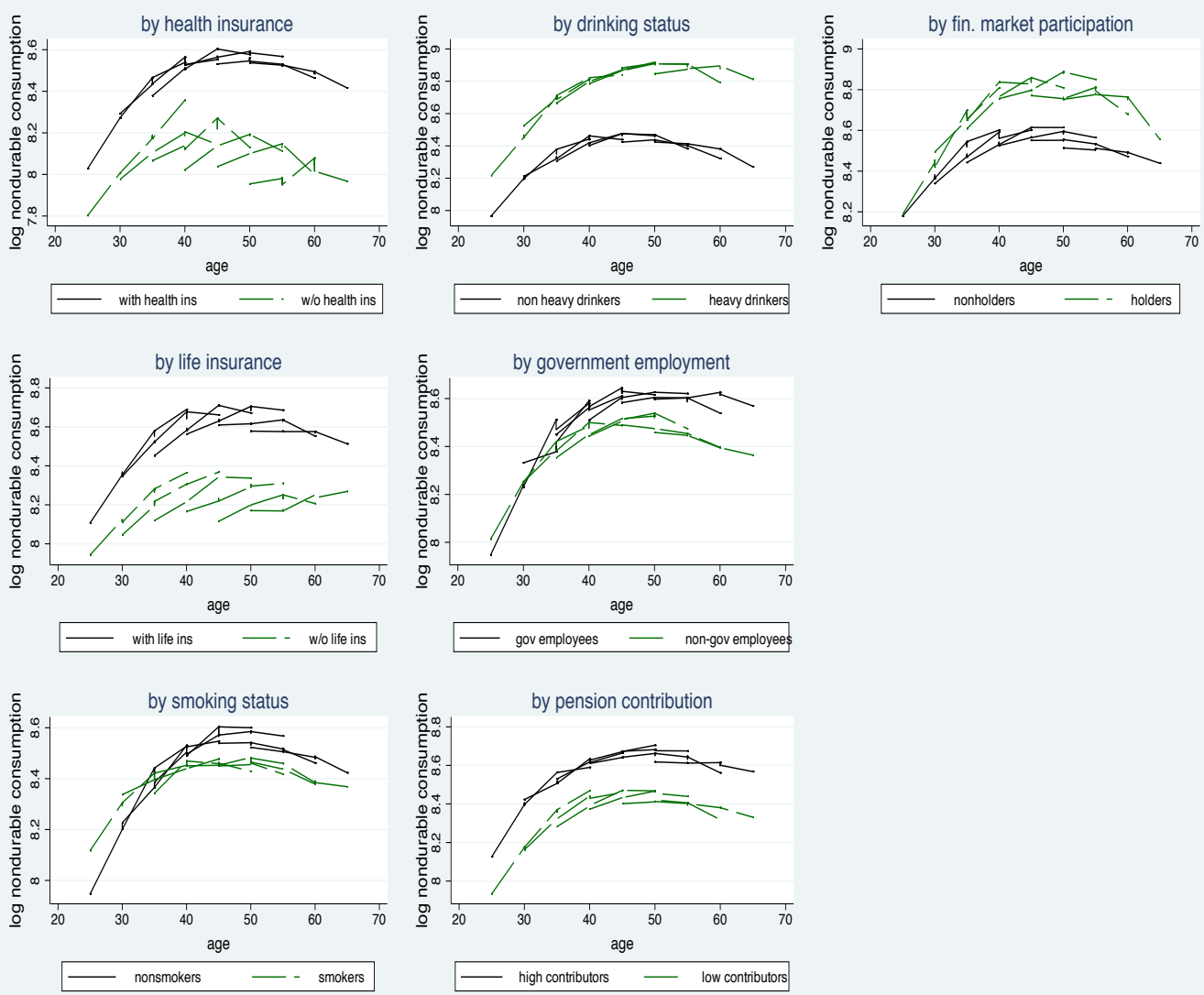